\title{
Benefits Derived from the Use of Information and Communication Technologies among Rural Farmers in Northeast Nigeria https://dx.doi.org/10.4314/iae.v23i3.10
}

\section{Yekinni, Oyedeji Taofeeq}

Department of Agricultural Extension and Rural Development, Faculty of Agriculture, University of Ibadan, Ibadan, Nigeria

Email: taofeegyekinni@gmail.com., Phone: +2348035905311.

\section{Ladigbolu, Tope Adejoju}

Department of Agricultural Extension and Rural Development, Faculty of Agriculture, University of Ibadan, Ibadan, Nigeria

Email: adejojutemitope@gmail.com., Phone: +2348035337569.

\section{Adeniyi, Rhoda Titilayo}

Department of Agricultural Extension and Rural Development, Faculty of Agriculture, University of Ibadan, Ibadan, Nigeria

Email: rt.adeniyi@yahoo.com., Phone: +2348027640111.

\section{Adebisi, Gbadebo Lukman}

Department of Agricultural Extension and Rural Development

Faculty of Agriculture, University of Ibadan, Ibadan, Nigeria

\begin{abstract}
The study investigated benefited from the use of ICTs in Northeastern Nigeria. A multistage sampling procedure was used to select 230 respondents. Data for the study were collected using interview schedule and analysed with percentages, mean and weighted score and Chi-square and PPMC at a0.05. Results show that the available ICT tools to the respondents were radio (97.4\%), mobile phone $(92.6 \%)$ and television (88.3\%). The most perceived benefits of ICTs were keeping in touch with friends with (158.8) and provision of information on weather, disease outbreak and new agricultural techniques (141.7). However, the majority (54.3\%) of the respondents had low level of benefit of ICT use. Constraint encountered using ICTs were high cost of maintenance (126.5), high call tariff (126.4) and language barrier (124.8). Significant relationship existed between respondents' age $(r=-0.61)$, sex $\left(X^{2}=56.50\right)$ and benefits derived from the use of ICTs. Respondents' low level of benefit derived could be due to language barrier, high cost of tariff and maintenance. Developmental practitioners should continue the use of ICTs to propagate information to target audience while high priority should be given to local language when packaging such information.
\end{abstract}

Keywords: ICTs, Rural farmer, new agricultural techniques, developmental practitioners, Northeast Nigeria 
Creative Commons User License: CC BY-NC-ND

Abstracted by: EBSCOhost, Electronic Journals Service (EJS),

Google Scholar, Journal Seek, Scientific Commons,

Food and Agricultural Organization (FAO), CABI and Scopus
Journal of Agricultural Extension

Vol. 23 (3) July, 2019

ISSN(e): 24086851; ISSN(Print); 1119944X

http://journal.aesonnigeria.org

http://www.ajol.info/index.php/iae

Email: editorinchief@aesonnigeria.org

\section{Introduction}

Information has been an important ingredient among the basic resources for the development of urban and rural settings of the developing countries especially when disseminated through information and communication technologies (ICTs). Descriptively, the communication devices which enable people to globally interact with one another, to access information promptly, and to communicate in and out of rural areas are ICTs (Oye, lahad and Zairah, 2012). According to Adeniyi and Yekinni (2015) and Ogbonna and Agwu (2013) ICTs like radio, television and mobile phone are the most available, accessible and utilised in the rural communities.

These ICTs are capable of capturing, coordinating, and processing and disseminate developmental information to a larger percentage of population at a given period of time. ICTs have been a great companion in sustainable developmental issues in remote areas as it enhances production capacity of the rural dwellers. Similarly, they can be used to breakdown both national and international barriers and turned the world into a universal village, through the available information to everyone, everywhere and at the needed time (Ogbonna and Agwu, 2013). Furthermore, ICTs can also facilitate new business models by providing financial services to the underprivileged, helping them to afford higher-quality inputs and to secure prompt payment for their outputs. The adoption of ICTs by rural dwellers has most direct impacts on agriculture and other rural livelihood activities that can enhance their increases in productivity, environmental sustainability, lower costs and greater value generation. More so, it permits access to information worldwide hence fostering empowerment of men, women and the youth in the communities (Mohammad and Shweta, 2014).

For instance, radio has been used to improve livestock production in Namibian, it has improved irrigation efficiency of Egyptian farmers, empowers women in agriculture and build human capacity (World Bank and the African Development Bank, 2012). Akin to these has been the contribution of mobile phone for improved social, environmental and economic development in African countries (Gerad, 2014). Mohammad and Shweta (2014) submit that access and utilisation of timely information by rural dwellers via ICTs is needful and helpful in carrying out their various non- agricultural and agricultural activities for their livelihood. In Northeast region of Nigeria more than $80 \%$ of the populace are engaged in growing of crops or rearing of livestock for their livelihood (Food and Agricultural Organisation (FAO), 2017). Therefore, they need information on their agricultural activities (crop farming as well as livestock production). Rural farmers' livestock information need include source of breeding stock, source of animal feed, location of range land, animal health, processing and marketing of animal and its products (Babayemi, Olaniyi, Abu, Okhiomah, Opakunbi and Ayotunde, 2014). In the same vein, there are several available ICT-based information in crop production that could be beneficial to these farmers, this is according to Ajani \& Agwu, (2012) and Akeweta, Tata \& James, (2018). Some of which are; information on pre-cultivation activities (crop selection, selection of the planting site, duration of sowing), cultivation and crop harvesting activities (preparation of land, sowing method, use of implement, sources of input, harvesting methods and dates). Finally, post-harvest activities (processing, transportation, storage and marketing). 
Creative Commons User License: CC BY-NC-ND

Abstracted by: EBSCOhost, Electronic Journals Service (EJS),

Google Scholar, Journal Seek, Scientific Commons,

Food and Agricultural Organization (FAO), CABI and Scopus
Journal of Agricultural Extension

Vol. 23 (3) July, 2019

ISSN(e): 24086851; ISSN(Print); 1119944X

http://journal.aesonnigeria.org

http://www.ajol.info/index.php/iae

Email: editorinchief@aesonnigeria.org

Rural dwellers are yearning for relevant developmental information on their livelihood, social and economic status in other to get empowered and maximize profits. It has been established that such developmental information can be convey via Information and Communication Technologies (ICTs) (Oye, lahad and Zairah, 2012). Despite the high $(108.67 \%)$ rate of tele-density in Nigeria (Nigerian Communication Commission (NCC), 2017); it is difficult for rural dwellers to retrieve information through ICTs, probably because of their poor technical know-how; as some of the communication infrastructures are not physically available in our rural areas. For example, most of the rural dwellers faced challenges such as irregular power supply and poor network problem. Furthermore, some of these ICTs with high technical know-how requires adequate training to be used. Rural dwellers are not also financially capable to acquire some of these ICTs or the required training for the use of the ICTs. This is coupled with unfavourable disposition of rural dwellers as they have a general believe that ICTs are actually for the wealth, educated of urban dwellers (United Nations Economic for Latin America and the Caribbean (ECLAC), Food and Agricultural Organisation (FAO), and Inter-American Institute for Cooperation on Agriculture (IICA), 2012). To address all these challenges and misconceptions there is need to identify, profile and organise all ICTs available as well as the benefits derived from using them, if there are any. Therefore, it is against this backdrop that this study investigated the benefits derived from the use of ICTs in the North-eastern part of the country.

Hence, the study ascertained the socioeconomic characteristics of the respondents, examined the available ICTs, constraints faced by the respondents to ICTs use, and benefits derived from the use ICTs. It was hypothesised that no significant relationship existed between the selected socioeconomic characteristics of the respondents and the benefit derived from the use of ICTs.

\section{Methodology}

The study was carried out in Northeast zone of Nigeria. Northeast lies between latitude $9^{0}$ $5^{\prime} \mathrm{N}$ to $13^{\circ} 44^{\prime} \mathrm{N}$ and longitude $9^{0} 50^{\prime} \mathrm{E}$ to $14^{\circ} 38^{\prime} \mathrm{E}$. Multistage sampling procedure was used to select respondents for the study. The first stage involved the selection of two states from the six states in Northeast zone using simple random sampling technique. The selected states are Adamawa and Taraba states. The second stage involved the stratification of local government area (LGAs) of the selected states into rural and urban. The third stage involved simple random selection of two rural LGAs each from the selected states giving four rural LGAs. The fourth stage involved simple random selection of two wards from each of the four rural LGAs selected which gave a total of eight wards. The fifth stage involved the simple random selection of two villages from each of the eight wards, in all sixteen villages were selected. The sixth stage of fifteen households from each of the sixteen villages, this means that 240 households were selected using systemic sampling technique. The selection was done by selecting the first household in every village, then subsequently the next three households was selected. Then any woman in the household was interviewed but the response rate was $96 \%$ of 240 expected sample size therefore in all 230 women were sampled for the study. Data were collected using structured interview schedule. Data collected were analysed using percentage, mean and weighted score and the Pearson Product Moment Correlation (PPMC) at $\alpha 0.05$. 
Creative Commons User License: CC BY-NC-ND

Abstracted by: EBSCOhost, Electronic Journals Service (EJS),

Google Scholar, Journal Seek, Scientific Commons,

Food and Agricultural Organization (FAO), CABI and Scopus
Journal of Agricultural Extension

Vol. 23 (3) July, 2019

ISSN(e): 24086851; ISSN(Print); 1119944X

http://journal.aesonnigeria.org

http://www.ajol.info/index.php/iae

Email: editorinchief@aesonnigeria.org

Availability of the ICT tools was measured by providing them with 12 possible ICTs that could be available to them in the study area with the response options of 'available' and 'not available. Response option 'available' was scored 1 and 'not available' was scored 0. Thereafter, the mean score for each available ICTs was determined and used to rank them. The ICT with the highest mean score of was ranked first while the ICT with the lowest mean score was ranked the least available ICT to the respondents respectively. Benefits derived from the use of ICTs was measured by providing respondents with 19 benefits items that could be derived from using any of the available ICTs. Benefit like keeping in touch with friends and family, providing information on weather condition, disease outbreak and new agricultural techniques, sending short messages and provide information on public health and so on. Response options of 'always', 'rarely' and 'not at all' were provided and these were assigned with scores of 2, 1, and 0 respectively. First of all, weighted score for each benefit item was computed and used in ranking the items. The ranking was done in such a way that an item with highest weighted score was ranked first among other benefit items while the one with the lowest weighted score was ranked the least item respectively. Similarly, benefits derived index determined and was used to categorised respondents into high and low level of benefit derived, this was done using the 'above and below the mean' criterion. Respondents' scores that fall within mean and above (54.017 - 128.00) was categorised high level of benefits derived while those that fall below mean ( 0 - 54.016) was categorized as having low benefits derived from the use of ICTs.

Constraints faced by the respondents in using the available ICTs were measured by asking respondents to indicate the severity at which they encountered any of the 13 constraints items they were provided with. Some of these constraints items are high cost of maintenance, high call tariff, language barrier, inadequate relevant information channel and poor reception of signals among others. Response options provided were "serious constraint", "mild constraint" and "not a constraint" while scores of 2, 1 and 0 were assigned respectively to each response options. Then weighted score for each constraint item was computed and used to rank the constraints faced by the respondent while using the available ICTs. The ranking was done in such a way that constraint item with highest weighted score was ranked first among other constraint items and the one with the lowest weighted score was ranked the least constraint faced in using the available ICTs. Respondents' socioeconomic characteristics like age, marital status, household size, sex, primary and secondary education and so on were measured on both nominal and interval level as the case dictates.

\section{Result and Discussion}

\section{Available ICTs}

Table 1 reveals that radio was ranked highest with mean score of 1.00 as the most available ICTs to the respondents. This is directly followed by mobile phone (0.93), television (0.88), computer (0.68) and newspaper (0.53). This implies that radio, mobile phone, television, computer and newspaper were the most commonly available ICTs to the respondents. This is in tandem with the findings of Akweta, et al (2018) who found out that the most commonly used ICTs are radio, television and mobile phone. The use of 
Creative Commons User License: CC BY-NC-ND

Abstracted by: EBSCOhost, Electronic Journals Service (EJS),

Google Scholar, Journal Seek, Scientific Commons,

Food and Agricultural Organization (FAO), CABI and Scopus
Journal of Agricultural Extension

Vol. 23 (3) July, 2019

ISSN(e): 24086851; ISSN(Print); 1119944X

http://journal.aesonnigeria.org

http://www.ajol.info/index.php/iae

Email: editorinchief@aesonnigeria.org

radio and mobile phone were ranked highest and this might because they are portable, user friendly and economical. This also is in line with the assertion of Ndaghu (2015) who found that radio is the most available ICTs in rural communities of Northern region of Nigeria. Similarly, newspaper was among the most available ICTs to rural dwellers. This is pointing to the fact that although the world is going paperless, (Chad, 2015) but people still rely on daily newspaper to retrieve news around the world. This could be probably because they are very cheap to obtain although some level of literacy is required.

Table 1: Availability of ICTs tools

\begin{tabular}{lll}
\hline ICTs Tools & Mean & Rank \\
\hline Radio & 1.00 & $1^{\text {st }}$ \\
Mobile phone & 0.93 & $2^{\text {nd }}$ \\
Television & 0.88 & $3^{\text {rd }}$ \\
Computer & 0.68 & $4^{\text {th }}$ \\
Newspaper & 0.54 & $5^{\text {th }}$ \\
Poster & 0.53 & $6^{\text {th }}$ \\
Internet & 0.44 & $7^{\text {th }}$ \\
Email & 0.37 & $8^{\text {th }}$ \\
Bulletin & 0.31 & $9^{\text {th }}$ \\
Newsletter & 0.30 & $10^{\text {th }}$ \\
Land phone & 0.26 & $11^{\text {th }}$ \\
Fax & 0.20 & $12^{\text {th }}$ \\
\hline
\end{tabular}

Source: Field survey, 2012

\section{Farmers Perceived Benefits of ICTs}

Table 2 shows that keeping in touch with friends and family was ranked first with weighted score of 158.8 among other benefits derived from the use of ICTs. This was closely followed by provision of information on weather condition, disease outbreak and new agricultural techniques (133.2), sending short messages (132.1), provide information on public health (124.0) and accessing information about business (123.5). These results show that respondents benefited immensely from the use of available ICTs to them. This implies that ICTs use is relevant to the respondents' social, livelihood and health affairs; and hence may be sustained in the study area. This corroborate the assertion of Ogbonna and Agwu (2013) that rural dwellers benefit a lot from the use of ICTs.

However, Table 2 indicates that more than half $(54.3 \%)$ of the respondents had low level of benefits derived from the use of ICTs. The implication is that the benefits respondents derived from the use of ICTs is relatively small. The low level of benefits derived could be as a results of some of the constraints such as high cost of maintenance, high call tariff and language barrier identified by the respondents on Table 3. 
Table 2: Farmers perceived benefit of ICTs

\begin{tabular}{lll}
\hline Benefits items & $\begin{array}{l}\text { Weighted } \\
\text { score }\end{array}$ & Rank \\
\hline Keeping in touch with friends and family & 158.8 & $1^{\text {st }}$ \\
Provide information on weather condition, disease outbreak and & 133.5 & $2^{\text {nd }}$ \\
new Agricultural techniques & 132.1 & $3^{\text {rd }}$ \\
Sending short messages & 124.0 & $4^{\text {th }}$ \\
Provide information on public health & 123.5 & $5^{\text {th }}$ \\
Accessing Information about business & 114.4 & $6^{\text {th }}$ \\
Provide information about the price of goods & 110.4 & $7^{\text {th }}$ \\
Provide information on processing activities & 106.5 & $8^{\text {th }}$ \\
Browsing & 105.3 & $9^{\text {th }}$ \\
Provide information about the location of the market & 103.9 & $10^{\text {th }}$ \\
Music & 89.5 & $11^{\text {th }}$ \\
Used to compute data & 84.0 & $12^{\text {th }}$ \\
Provide government related information to the citizen & 83.4 & $13^{\text {th }}$ \\
Social networking (Facebook, twitter) & 81.8 & $14^{\text {th }}$ \\
Advertising business & 78.8 & $15^{\text {th }}$ \\
To access economic and agricultural policy & 73.1 & $16^{\text {th }}$ \\
Provide ideal platform for local voices to be heard & 71.4 & $17^{\text {th }}$ \\
Used to sell and buy products all over the world & 63.6 & $18^{\text {th }}$ \\
Watching of films & 63.0 & $19^{\text {th }}$ \\
Read news & $\%$ & \\
\hline Level of benefits & 54.3 & \\
\hline High & 45.7 & \\
Low & & \\
\hline Source: Field Survey, 2012 & & \\
\hline
\end{tabular}

\section{Source: Field Survey, 2012}

\section{Constraints to Use of ICTs}

Table 3 shows that the most severe constraint faced by the respondents to the use of ICTs was high cost of maintenance (126.5) with the highest weighted score, this is followed by high call tariff (126.4), irrelevant information channel (125.6), language barrier (124.8) and maintenance of tools or equipment (124.0) were ranked third, fourth and fifth respectively. This implies that high cost of maintenance, high call tariff, inadequate relevant information channel, language barrier and maintenance of tools or equipment are challenges that may hinder respondents' maximum benefits from the use of ICTs. This is in tandem with the findings of Badiru, Balogun and Ladigbolu, (2019); Tyabo, Adesiji, Ibrahim, Usar and Ndanista (2015); Ladele, Ladigbolu and Badiru, 2014) in similar studies where language barrier, high call tariff and maintenance were the most constraint to the use of some ICTs like mobile phone and radio. 
Table 3: Constraints to use of ICTs

\begin{tabular}{lll}
\hline Constraint items & $\begin{array}{l}\text { Weighted } \\
\text { score }\end{array}$ & Rank \\
\hline High cost of maintenance & 126.5 & $1^{\text {th }}$ \\
High call tariff & 126.4 & $2^{\text {th }}$ \\
Inadequate relevant information channel & 125.6 & $3^{\text {th }}$ \\
Language barrier & 124.8 & $4^{\text {th }}$ \\
Maintenance of tools and equipment & 124.0 & $5^{\text {th }}$ \\
Repair technical fault & 123.9 & $6^{\text {th }}$ \\
Poor reception of signals & 121.4 & $7^{\text {th }}$ \\
Unavailability and cost of batteries & 121.3 & $8^{\text {th }}$ \\
Short duration of programme & 117.8 & $9^{\text {th }}$ \\
Complicated to understand & 115.6 & $10^{\text {th }}$ \\
Access to recharge purchasing centres & 110.1 & $11^{\text {th }}$ \\
Lack of adequate time to listen to information & 97.8 & $12^{\text {th }}$ \\
Time of transmission & 94.7 & $13^{\text {th }}$ \\
\hline
\end{tabular}

Source: Field survey, 2012

\section{Relationship between Socioeconomic Characteristics and Benefits Derived}

The result in Table 4 reveals that respondents' age $(r=-0.61)$ had an inverse significant relationship with the benefit derived from the use of ICTs. This implies that the younger the respondents, the more the benefits derived from the use of ICTs. This could be because of youth's interest and energy in searching and exploring more information hence the more the benefits they derive. Similarly, there is positive significant relationship between years of formal education $(r=0.13)$, sex $\left(x^{2}=56.50\right)$, religion $\left(x^{2}=162.92\right)$ and benefits derived from the use of ICTs. This implies that their level of education, sex and religion enhances utilisation of ICTs hence, high benefit derived as affirmed by Nenna (2016). However, there is no significant relationship between respondents' household size $(r=0.80 ; p=0.23)$, income $(r=0.08 ; p=0.22)$ and benefits derived from the use of ICTs. This implies that neither does household size nor income earned by the respondents was responsible for the benefits they derived from the use of ICTs. That is, the benefits derived from the ICTs used were independent of the size of their household and their earnings. This could probably be better explained by referring to findings of this study earlier reported in Table 1. It was reported that respondents are have large family size and are small income earners. First off, that they are small income earners should not stop them from deriving benefits from the use of ICTs, this is because the most available ICTs to these set of people are relatively affordable for example radio, television and mobile phones (see Table 2). They probably do not need to buy these ICTs every year, once they acquire them, they could be used for a longer period of time if not stolen, hence they could derive benefit by using them on a daily basis. In fact, an ICT like mobile phone often come with radio, hence they might not need to buy a separate radio set. Similarly, the family size might not also affect the rate at which respondents derive benefits because number of people living in a household should not deterred them from gaining from the use of ICTs. For example, a radio or television set can serve a hundred of people in the household or even few. 
Table 4: Relationship between the selected socioeconomic characteristics of the respondents and the benefit derived from the ICTs used

\begin{tabular}{lll}
\hline Variables & r-value & \\
\hline Age & $-0.61^{*}$ & \\
Years of former education & $0.13^{*}$ & \\
Household size & 0.80 & \\
Income & 0.08 & Df \\
\hline Variables & $\mathbf{X}$-value & 1 \\
\hline Sex & $56.50^{\star}$ & 2 \\
Religion & $162.92^{\star}$ &
\end{tabular}

\section{Conclusion and Recommendations}

The most available and commonly used ICTs in the rural areas are radio, mobile phone and television. Respondents benefited immensely from the use of available ICTs socially and for their farming activities. The younger respondents, the more the benefits derived from the use of ICTs. Developmental practitioners should continue the use of ICTs to propagate information to target audience especially in the rural areas while high priority should be given to local language when packaging such information.

\section{References}

Adeniyi, R. T. and Yekinni, O. T. (2015). Arable crop farmers' characteristics affecting the utilization of information and communication technology for agricultural marketing information in Oyo State, Nigerian. Journal of Rural Sociology, 15(2), 23-29.

Ajani E. N. and A. E. Agwu A. E (2012): Information communication technology needs of small-scale farmers in Anambra State, Nigeria, Journal of Agricultural \& Food Information, 13(2), 144-156. http://dx.doi.org/10.1080/10496505.2012.663694

Akeweta, J. N., Tata, L. A. and James, A. N. (2018). Information needs of farmers in Song Local Government area, Adamawa State, Nigeria. Journal of Agriculture, Food security and Sustainable environment, 1(1), 11.

Babayemi, O. J., Abu, O. A. and Opakunbi, A. (2014). Integrated animal husbandry for school and colleges, 102-251. Positive press ISBN: 978-978-52033-3-2.

Badiru, I. O., Balogun, O. K. and Ladigbolu, T. A. (2019). Rural dwellers' perception of the effects of mobile phone usage on their livelihood activities in Oyo state, Nigeria. Conference Proceedings of the Sustainable Livelihoods and Development Network for Africa (SLIDEN AFRICA, ACCRA) held at Oscarpark Hotel, off Kisseman Road, West Legon, Accra, Ghana 322- 327.

Chad Chao (2015). Implementing a paperless system for Small and Medium-Sized Businesses (SMBs). Applied Information Management and the Graduate School of the University of Oregon in partial fulfilment of the requirement for the degree of Master of Science, 1-56. https://scholarsbank.uoregon.edu/xmlui/bitstream/handle/1794/19630/Chao2015.pdf

Gerard, S. (2014). Information and Communication Technologies for sustainable agriculture. Indicator for Asia and the pacific, 1-122. ISBN 978-92-5-108107-5. 
Ladele, A. A., Ladigbolu, T. A. and Badiru, I. O. (2014). Factors affecting the Listenership of Enlightenment Programmes on University of Ibadan Community Radio. Proceedings of Agricultural Extension. pp11.

Mohammad, A. A. and Shweta, S. (2014). Agriculture Information needs of farm women: A study in State North India. African Journal of Agricultural Research, 9(9), 10. DOI:10.5897/AJAR 2014.8503. ISSN 1991-637X.

Ndaghu, A. A. (2012). Use of information communication technologies (ICTs) among women farmers in Northeastern Nigeria. An unpublished Thesis in the Department of Agricultural development, University of Ibadan, Nigeria, 131-183.

Nenna, M. G. (2014). Assessment of information and communication technologies (ICTs) among cassava farmers in Anambra State, Nigeria. British Journal of Research, BJR 3(2), 1-13. (www.brithishjr.org), Medical Publishing, ISSN, 2394-3718.

Nigerian Communication Commission (NCC) (2017). Nigeria Teledensity hits $108.665 \%$ on Monday $10^{\text {th }}$ April, 2017. https://www.today.ng/technology/90458/nigeriasteledensity-hits-108-66. Accessed 16th April, 2017

Ogbonna, O. I, and Agwu, A. E. (2013). Access and use of information communication technologies by rural farmers in Enugu North Senatorial Zone, Enugu State. Scholarly Journal of Agricultural Science, 3(7), 264-270. Available Online At Http:// Www. Scholarly-Journals.Com/SJAS ISSN 2276-7118.

San Joes Coaster Rica. Food and Agricultural Organisation of the United Nation (2017). Northeastern Nigeria situation report. January 2017.

Tyabo, I. S., Adesiji, G. B., Ibrahim, M., Umar, I. S. and Ndanista, M. A. (2015). Perceived effect of mobile phone and livelihood of rural dweller in Niger State Nigeria. Proceedings- $20^{\text {th }}$ Annual National Conference of the Agricultural extension Society of Nigeria held at the National Agricultural Extension and Research Liason services (NAERLS), Ahmadu Bello University, Zaria (15 th $^{\text {t }} 17^{\text {th }}$, may, 2015), 200-209. ISSN: 1995-1421.

United Nations Economic for Latin America and the Carribbean (ECLAC), Food and Agricultural Organisation (FAO), and Inter-American Institute for Cooperation on Agriculture (IICA) (2012). ICTs and the new challenges for Agricultural and rural development. The outlook for Agriculture and Rural Development in the Americas; A perspective on Latin America and the Caribean, 115-139.

World Bank and the Africa Development Bank (2012). Information Communication Technologies for Agriculture, 1-29. 